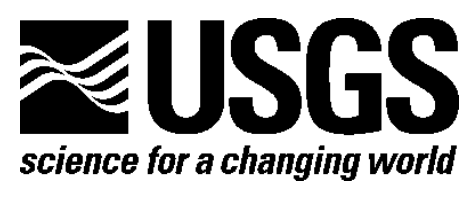

\title{
Correction of Elevation Offsets in Multiple Co-located Lidar Datasets
}

By David M. Thompson, P. Soupy Dalyander, Joseph W. Long, and Nathaniel G. Plant

Open-File Report 2017-1031

U.S. Department of the Interior U.S. Geological Survey 


\section{U.S. Department of the Interior \\ RYAN K. ZINKE, Secretary}

\section{U.S. Geological Survey \\ William H. Werkheiser, Acting Director}

U.S. Geological Survey, Reston, Virginia: 2017

For more information on the USGS - the Federal source for science about the Earth, its natural and living resources, natural hazards, and the environment-visit http://www.usgs.gov/ or call 1-888-ASK-USGS (1-888-275-8747).

For an overview of USGS information products, including maps, imagery, and publications, visit http://store.usgs.gov.

Any use of trade, firm, or product names is for descriptive purposes only and does not imply endorsement by the U.S. Government.

Although this information product, for the most part, is in the public domain, it also may contain copyrighted materials as noted in the text. Permission to reproduce copyrighted items must be secured from the copyright owner.

\section{Suggested citation:}

Thompson, D.M., Dalyander, P.S., Long, J.W., and Plant, N.G., 2017, Correction of elevation offsets in multiple co-located lidar datasets: U.S. Geological Survey Open-File Report 2017-1031, 10 p., https://doi.org/10.3133/ofr20171031.

ISSN 2331-1258 (online) 


\section{Contents}

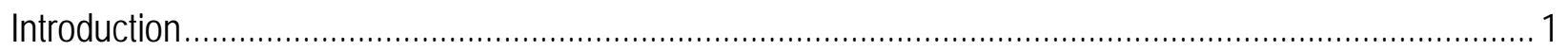

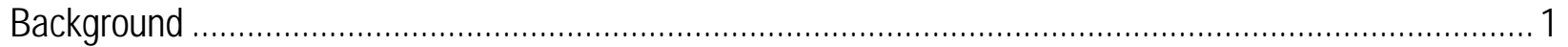

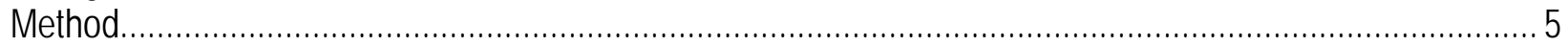

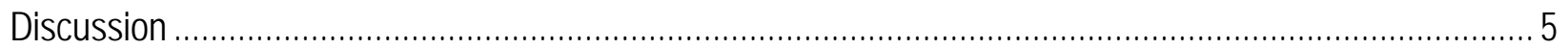

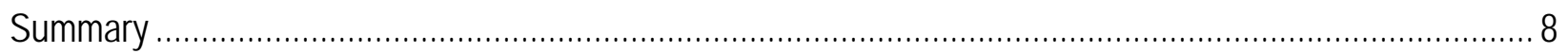

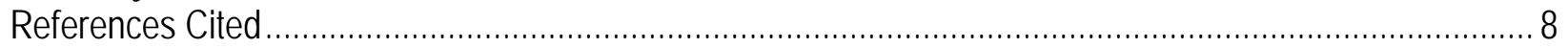

\section{Figures}

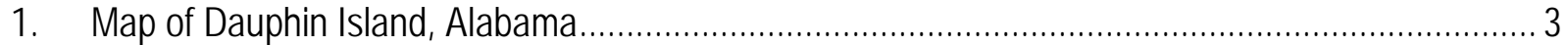

2. Maps showing the change in elevation from January, 2010, to July, 2010, on the west $(A)$ and east

$(B)$ ends of Dauphin Island before applying bias offset correction ............................................ 4

3. A, Aerial view of study area showing locations of lidar elevation comparisons used for elevation corrections. $B$, Offset between the survey elevation and the long-term mean at each location, and mean offset calculated for each survey..

4. Maps showing the change in elevation from January, 2010, to July, 2010, on the west $(A)$ and east $(B)$ ends of Dauphin Island after applying bias offset correction.

\section{Tables}

1. Lidar dataset inventory for Dauphin Island, Alabama 


\section{Conversion Factors}

U.S. customary units to International System of Units

\begin{tabular}{|c|c|c|}
\hline Multiply & By & To obtain \\
\hline \multicolumn{3}{|c|}{ Length } \\
\hline inch (in.) & 2.54 & centimeter $(\mathrm{cm})$ \\
\hline foot $(\mathrm{ft})$ & 0.3048 & meter $(\mathrm{m})$ \\
\hline mile (mi) & 1.609 & kilometer $(\mathrm{km})$ \\
\hline
\end{tabular}

International System of Units to U.S. customary units

\begin{tabular}{|c|c|c|}
\hline Multiply & By & To obtain \\
\hline \multicolumn{3}{|c|}{ Length } \\
\hline centimeter $(\mathrm{cm})$ & 0.3937 & inch (in.) \\
\hline meter $(\mathrm{m})$ & 3.281 & foot (ft) \\
\hline kilometer $(\mathrm{km})$ & 0.6214 & mile (mi) \\
\hline
\end{tabular}

\section{Datum}

Vertical coordinate information is referenced to the North American Vertical Datum of 1988 (NAVD 88).

Horizontal coordinate information is referenced to the North American Datum of 1983 (NAD 83).

Elevation, as used in this report, refers to distance above the vertical datum.

\section{Abbreviations}

$\begin{array}{ll}\text { GPS } & \text { global positioning system } \\ \text { JALBTCX } & \text { Joint Airborne Lidar Bathymetry Technical Center of Expertise } \\ \text { NASA } & \text { National Aeronautics and Space Administration } \\ \text { NOAA } & \text { National Oceanic and Atmospheric Administration } \\ \text { RMS } & \text { root mean square } \\ \text { U.S. } & \text { United States } \\ \text { USACE } & \text { U.S. Army Corps of Engineers } \\ \text { USGS } & \text { U.S. Geological Survey }\end{array}$




\title{
Correction of Elevation Offsets in Multiple Co-located Lidar Datasets
}

\author{
By David M. Thompson, P. Soupy Dalyander, Joseph W. Long, and Nathaniel G. Plant
}

\section{Introduction}

Topographic elevation data collected with airborne light detection and ranging (lidar) can be used to analyze short- and long-term changes to beach and dune systems. Analysis of multiple lidar datasets at Dauphin Island, Alabama, revealed systematic, island-wide elevation differences on the order of $10 \mathrm{~s}$ of centimeters $(\mathrm{cm})$ that were not attributable to real-world change and, therefore, were likely to represent systematic sampling offsets. These offsets vary between the datasets, but appear spatially consistent within a given survey. This report describes a method that was developed to identify and correct offsets between lidar datasets collected over the same site at different times so that true elevation changes over time, associated with sediment accumulation or erosion, can be analyzed.

\section{Background}

Lidar data are collected and processed by entities including the U.S. Geological Survey (USGS), U.S. Army Corps of Engineers (USACE), National Oceanic and Atmospheric Administration (NOAA), and private firms. Elevation data can be vertically referenced to tidal datums such as mean sea level (MSL) or geodetic datums such as the North American Vertical Datum of 1988 (NAVD 88). Conversions between vertical datums are accomplished via software programs such as the NOAA "VDatum" tool (http://vdatum.noaa.gov/), and rely on the use of a model of the geoid (a best fit to global mean sea level) that has been updated over time (for example, GEOID96, GEOID09, GEOID12, etc., with the digits indicating the year of update).

Recent lidar datasets are typically processed to provide both "first return" and "last return" topography, where the former generally provides the elevation of vegetation canopies and the latter is used to derive a bare earth signal, reflecting the elevation beneath vegetation (Doran and others, 2010). Similar techniques are also sometimes used to remove houses and other buildings from the data. Here, we utilize last return (bare earth) data to assess lidar elevation differences.

Lidar datasets that are calibrated with ground-truth elevation data are estimated to have a root mean squared error (RMSE) on the order of 10 to $25 \mathrm{~cm}$ (Nayegandhi and others, 2009a; Wright and others, 2014). Ground control surveys are not always conducted or used to calibrate every survey, however, both calibrated and non-calibrated data can include error due to a number of other factors. The type of terrain and presence of vegetation may introduce errors, as will inaccuracy in the Global Positioning System (GPS) and aircraft altitude measurements. In some older datasets, only the first return data are available, and offsets may result when comparing it to bare earth datasets. Other errors may be associated with flight navigation and the individual 
lidar system, or introduced during conversion between vertical datums. These errors may result in sampling biases in the elevation data, and positive and negative offsets in this vertical bias can introduce systematic and potentially cumulative error when calculating elevation change between surveys.

Elevation differences consistent with sampling biases were observed during analysis of 15 lidar datasets (table 1) collected over a 16-year period at Dauphin Island, Alabama (fig. 1). Initial analysis showed consistent elevation differences over the entire island between certain consecutive surveys (for example, January, 2010, to July, 2010) (fig. 2). Because it is extremely unlikely that the island incurred spatially uniform erosion or accretion, these offsets were assumed to be differences in bias between the surveys and not real world changes. The method presented here was developed to correct these bias offsets so that elevation differences between corrected surveys are attributable to the physical evolution of the island.

Table 1. Lidar dataset inventory for Dauphin Island, Alabama.

[Some surveys did not include coverage of all nine locations used to correct bias offsets between datasets, as indicated below. Bias offset $\left(\Delta Z_{S}\right)$ is the elevation difference $(\Delta \mathrm{Z})$ in meters at the survey $(S)$ location. Additional abbreviations: mm, month; yyyy, year.]

\begin{tabular}{|c|c|c|c|c|}
\hline $\begin{array}{c}\text { Date } \\
\text { (mm/yyyy) }\end{array}$ & Reference & $\begin{array}{l}\text { Return } \\
\text { type }\end{array}$ & $\begin{array}{c}\text { Bias offset } \\
\left(\Delta Z_{S} ; \text { in }\right. \\
\text { meters })\end{array}$ & $\begin{array}{l}\text { Number of survey } \\
\text { locations used to } \\
\text { compute bias offset } \\
\text { (n) }\end{array}$ \\
\hline $11 / 1998$ & NOAA, USGS, and NASA (2000) & First & -0.31 & 9 \\
\hline 09/2001 & Nayegandhi and others $(2009 b)$ & First & -0.10 & 4 \\
\hline $05 / 2004$ & JALBTCX (2006) & Last & 0.09 & 9 \\
\hline 09/2004 & Nayegandhi and others (2008) & First & 0.02 & 4 \\
\hline 09/2005 & Kranenburg and others (2016a) & Last & -0.12 & 9 \\
\hline $03 / 2006$ & Long and others (2016a) & Last & -0.42 & 4 \\
\hline 09/2006 & Long and others (2016b) & Last & -0.26 & 9 \\
\hline 06/2007 & Smith and others (2008) & Last & -0.17 & 9 \\
\hline 06/2008 & Long and others (2016c) & Last & -0.17 & 9 \\
\hline 09/2008 & Bonisteel-Cormier and others (2010) & Last & 0.09 & 9 \\
\hline $01 / 2010$ & NOAA and JALBTCX (2011) & Last & -0.12 & 9 \\
\hline 07/2010 & Kranenburg and others (2016b) & Last & 0.13 & 8 \\
\hline $06 / 2011$ & NOAA and JALBTCX (2013) & Last & -0.15 & 9 \\
\hline 09/2012 & Guy and others (2014) & Last & 0.39 & 9 \\
\hline $07 / 2013$ & Guy and Plant (2014) & Last & -0.13 & 9 \\
\hline
\end{tabular}




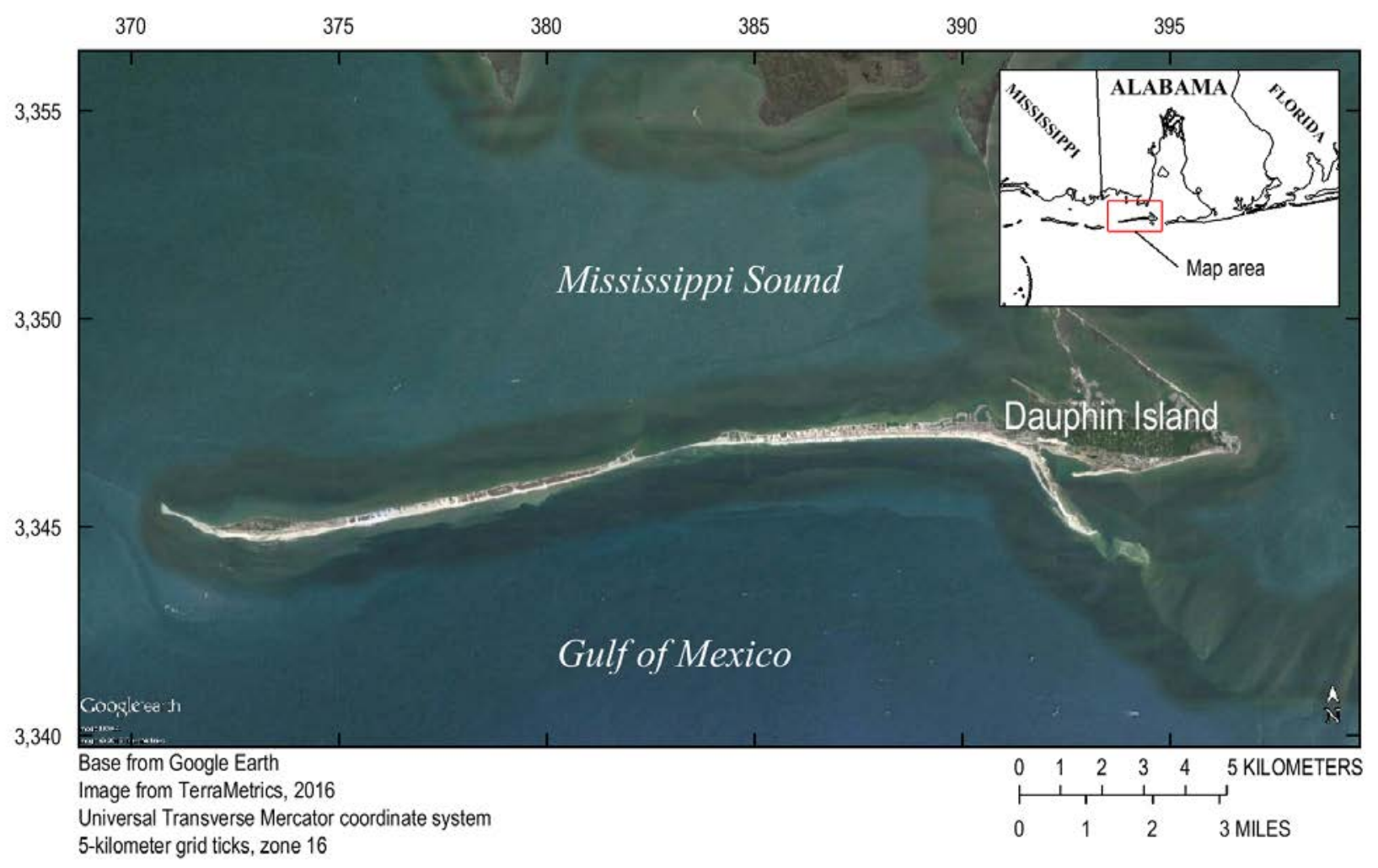

Figure 1. Map of Dauphin Island, Alabama. 
A
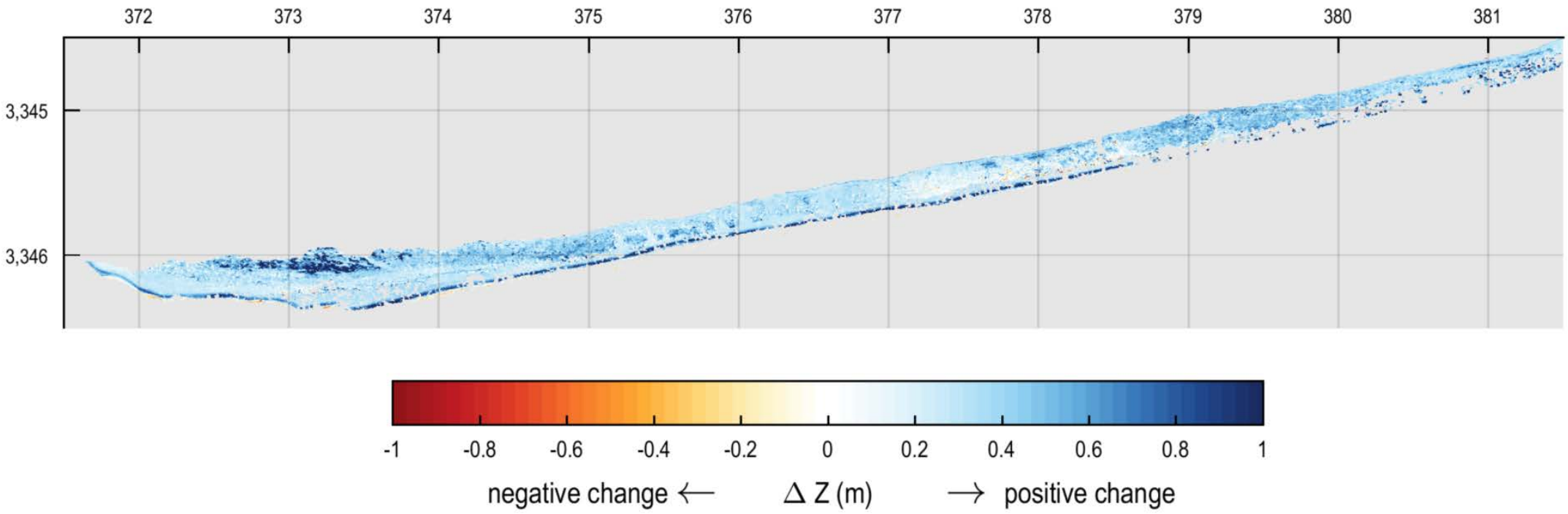

B

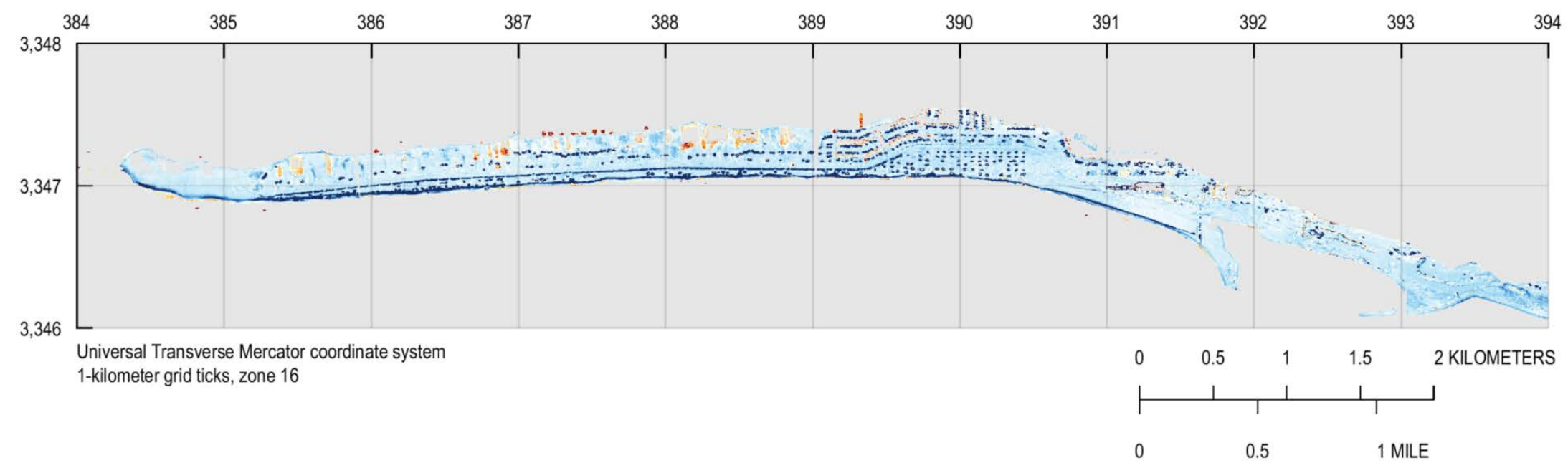

Figure 2. Maps showing the change in elevation from January, 2010, to July, 2010, on the west $(A)$ and east $(B)$ ends of Dauphin Island before applying bias offset correction. The blue squares in $B$ are houses that were present in the January, 2010, survey, but were removed from the dataset during processing of the July, 2010 , survey. " $\Delta Z$ " is the change in elevation in meters (m). 


\section{Method}

The technique used here consists of adjusting lidar surveys to a common, baseline elevation. At Dauphin Island, nine reference locations were identified on roads and parking lots that should remain relatively vertically stable over time. These locations were chosen in the higher elevation, eastern portion of the island, where roads are not prone to overwash and sand deposition during strong storms (fig. 3A). The elevation $\left(Z_{S, L}\right)$ for each survey at each reference location was calculated as the mean elevation of all lidar data points within a 3 -meter $(\mathrm{m})$ radius. The baseline elevation for each reference location was then calculated as the long-term mean elevation $\left(Z_{L}\right)$ averaged over the number of surveys that included data at that location $(N)$, using equation 1:

$$
Z_{L}=\frac{\sum_{S=1}^{N} Z_{S, L}}{N}
$$

Not all surveys had spatial coverage at all reference locations (table 1). The difference between the elevation of each survey and the baseline elevation at each of the reference points $\left(\Delta Z_{S, L}\right)$ was then calculated using equation 2 as:

$$
\Delta Z_{S, L}=Z_{S, L}-Z_{L}
$$

Finally, using equation 3 , the offset of each survey from the reference elevation was averaged over all locations (fig. $3 B$ ) as:

$$
\Delta Z_{S}=\frac{\sum_{L=1}^{n} \Delta Z_{S, L}}{n}
$$

Where $n$ is the number of locations with observations for a particular survey, S. This offset was added to all of the data points in that survey to adjust it to the reference elevation (fig. 4).

\section{Discussion}

The corrected survey elevations minimize the relative offsets that are due to the sampling bias errors. But, without independent estimates of elevation at the reference points, the absolute offsets relative to a tidal datum are not necessarily corrected. However, the methodology developed here allows the true physical change of beach and dune elevation between multiple lidar datasets to be calculated more accurately by adjusting surveys to a common baseline elevation, thus removing offsets in bias between surveys that can lead to systematic errors. This relative change is the primary interest in studying beach and dune erosion and accretion processes. Reducing the bias offset is particularly important in accretion processes such as dune building, when the change in elevation between surveys that are months to years apart may be on the order of 10 s of centimeters. 
$A$

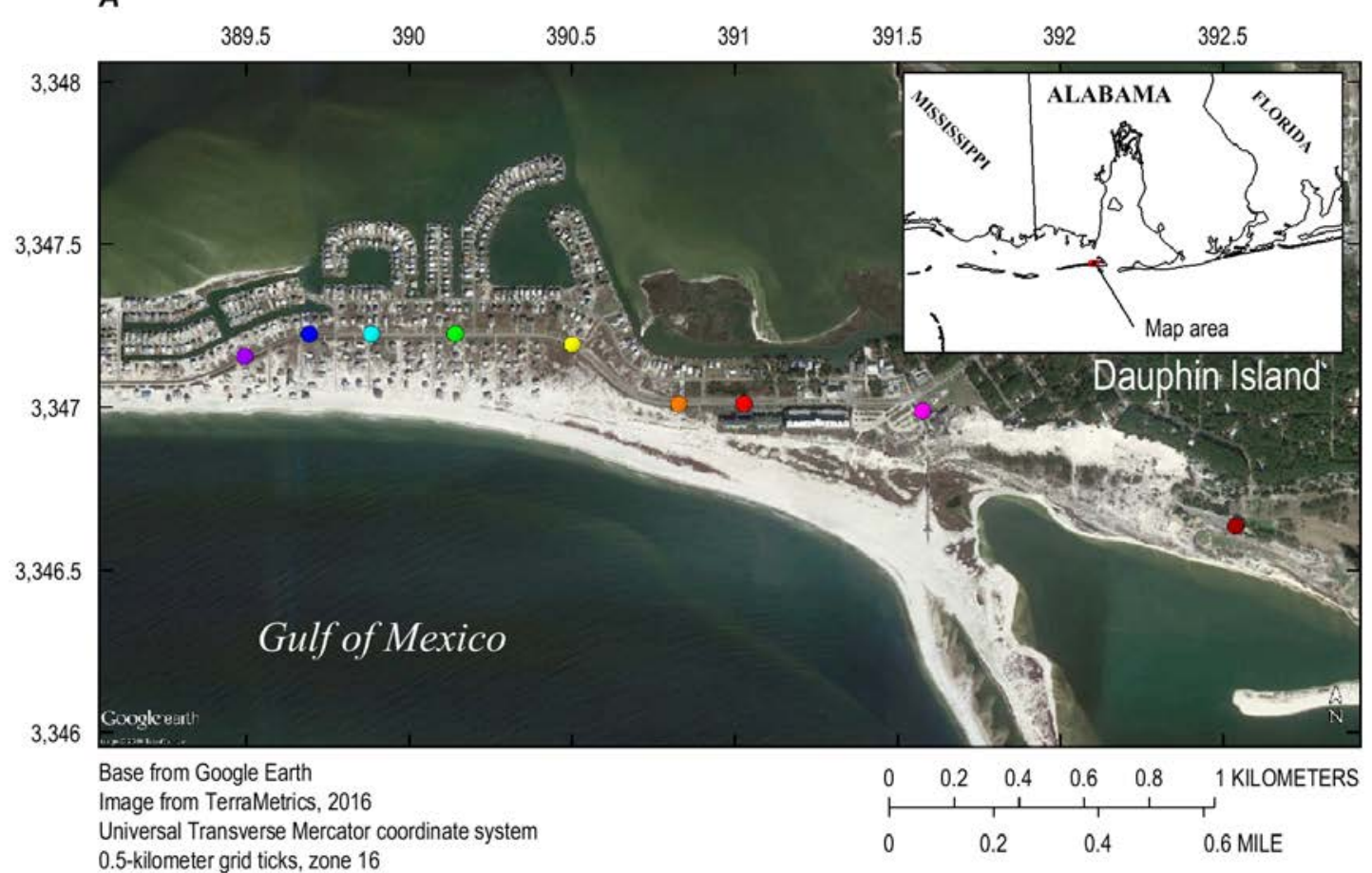

$B$

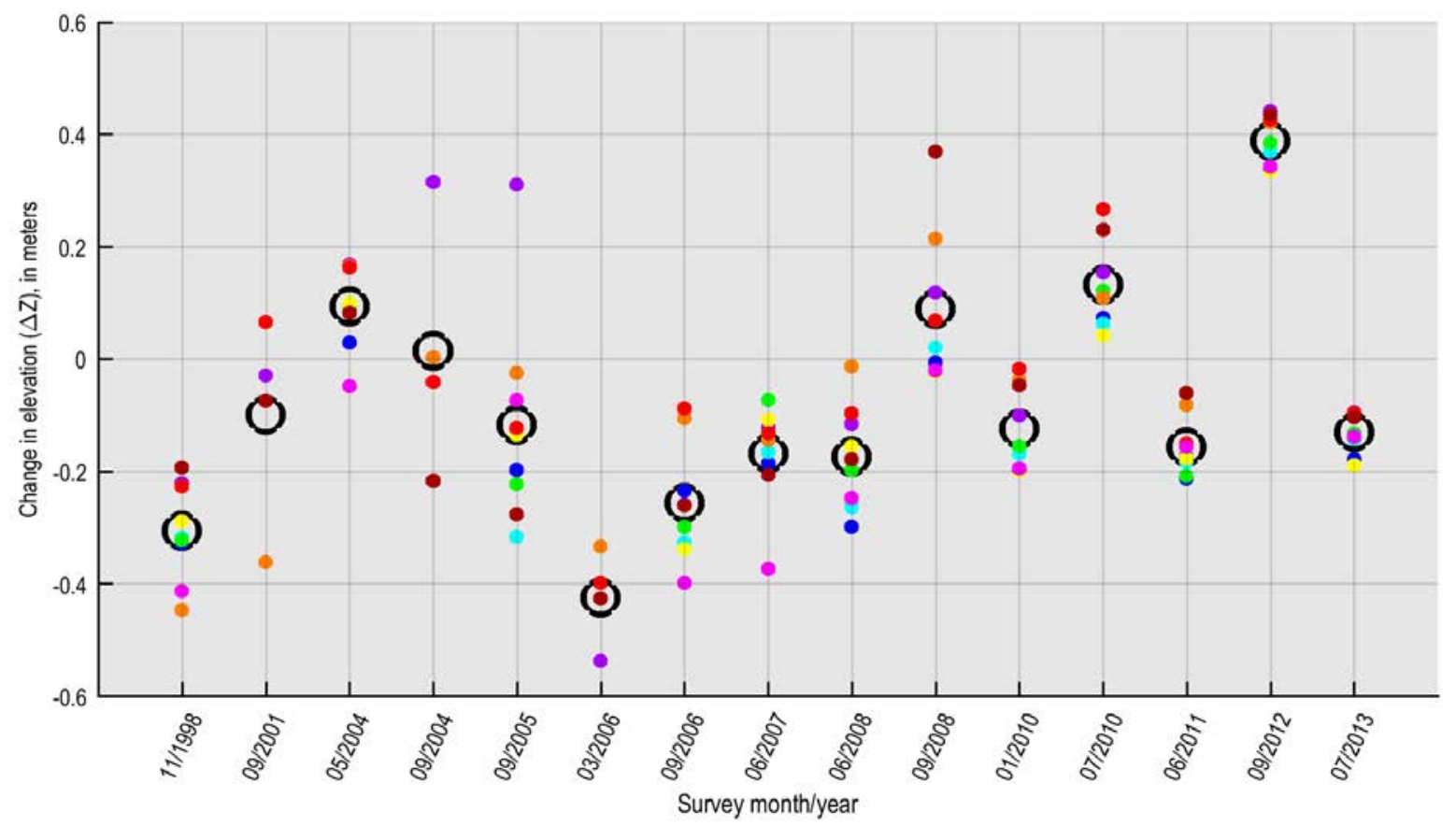

Figure 3. A, Aerial view of study area showing locations (colored dots) of lidar elevation comparisons used for elevation corrections. $B$, Offset between the survey elevation and the long-term mean at each location, $\Delta Z_{S, L}$ (colored dots), and mean offset calculated for each survey, $\Delta Z_{S}$ (black circles). Colored dots correspond to survey locations indicated on the aerial view in $A$. 

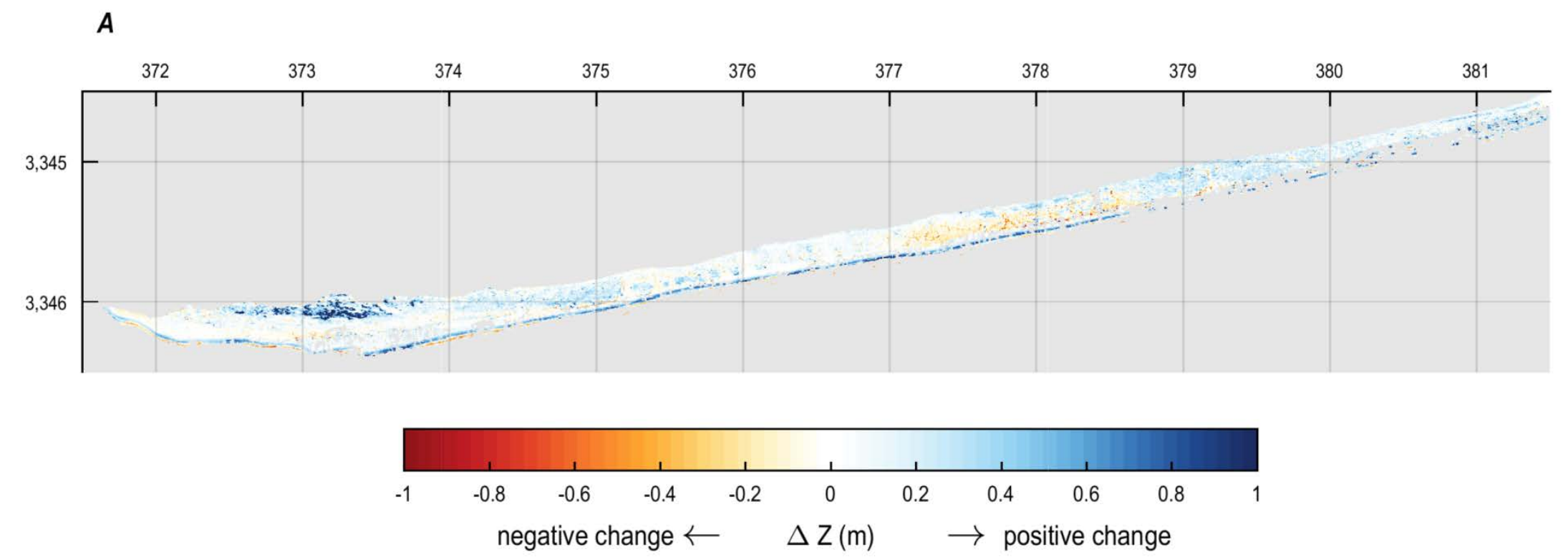

\section{$B$}

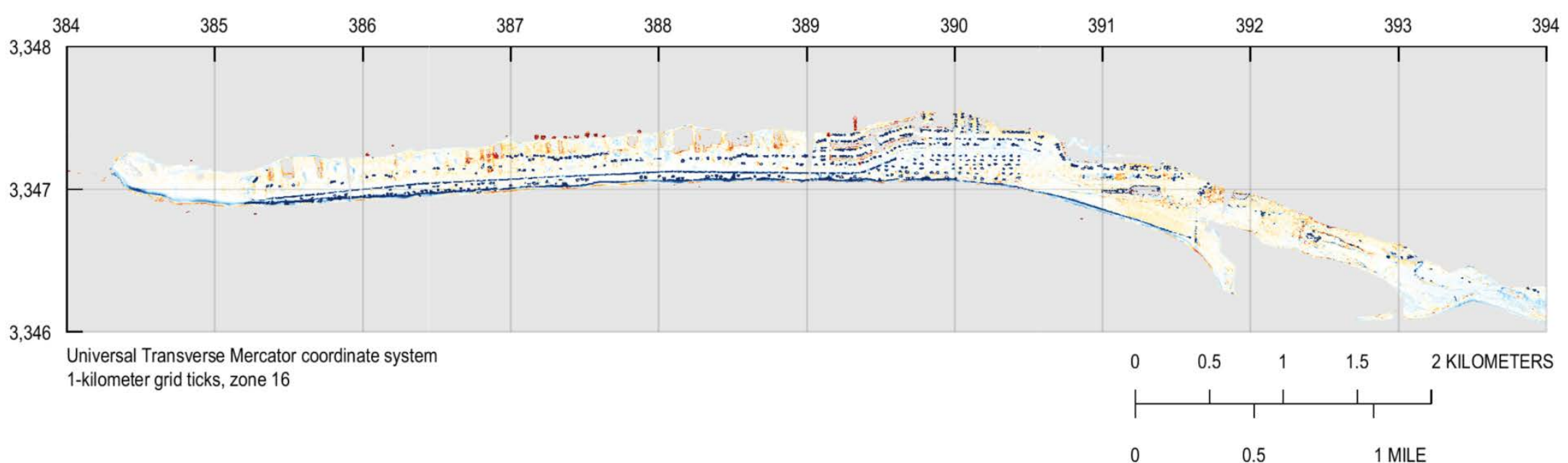

Figure 4. Maps showing the change in elevation from January, 2010, to July, 2010, on the west $(A)$ and east $(B)$ ends of Dauphin Island after applying bias offset correction. The blue squares in $B$ are houses that were present in the January, 2010, survey, but were removed from the dataset during processing of the July, 2010, survey. " $\Delta Z$ " is the change in elevation in meters (m). 
The methodology developed here could be applied to any sequence of lidar surveys that include locations where the true vertical elevation is reasonably fixed (such as roads, bridges, and parking lots). The number of surveys adjusted can be as few as two, presuming they both included spatial coverage of reference locations. This technique could also be applied using fewer reference locations. However, doing so would increase the weighting of any outlier data in the calculation of the long-term mean reference elevations and survey offsets, which introduces error. Increasing the radius of each reference location would capture more points for any given survey, thus minimizing the potential influence of outlier data points, but with a trade-off that would include a larger spatial area of potentially non-uniform elevation. If multiple reference locations were distributed throughout the survey area of interest, a spatially variable offset could be calculated. In the case of Dauphin Island, suitable reference locations were all located at the eastern end of the island; therefore, the bias offsets were assumed to be spatially uniform in this application.

\section{Summary}

Lidar data may contain vertical bias errors of 10 to $25 \mathrm{~cm}$, which can be cumulative when analyzing elevation change between multiple surveys at the same location. A methodology was developed to adjust lidar datasets to a common baseline elevation, thus removing the offset in bias between multiple surveys. A time-averaged mean elevation was calculated at nine reference locations where vertical change is assumed to be minimal (roads and parking lots). The difference between this time-averaged elevation and the elevation in any particular survey was taken as the offset to the baseline elevation for each reference location. A mean offset (over all reference locations) was then calculated for each survey, and ranged from -42 to $+39 \mathrm{~cm}$. These offsets can be removed from the lidar data to allow more robust calculation of true beach, dune, and other physical changes. This technique may be applied at any site where multiple lidar surveys have been completed that include fixed-elevation reference locations.

\section{References Cited}

Bonisteel-Cormier, J.M., Nayegandhi, Amar, Wright, C.W., Sallenger, A.H., Brock, J.C., Nagle, D.B., Klipp, E.S., Vivekanandan, S., Fredericks, X., and Segura, M., 2010, EAARL coastal topography-Mississippi and Alabama barrier islands, post-Hurricane Gustav, 2008: U.S. Geological Survey Data Series 556, accessed July 12, 2016, at http://pubs.usgs.gov/ds/556/. Doran, K.J., Sallenger, A.H, Reynolds, B.J., and Wright, C.W., 2010, Accuracy of EAARL lidar ground elevations using a bare-earth algorithm in marsh and beach grasses on the Chandeleur Islands, Louisiana: U.S Geological Survey Open-File Report 2010-1163, 9 p., accessed July 12, 2016, at https://pubs.usgs.gov/of/2010/1163/.

Guy, K.K., Doran, K.J., Stockdon H.F., and Plant, N.G., 2014, Topographic lidar survey of the Alabama, Mississippi, and southeast Louisiana barrier islands, from September 5 to October 11, 2012: U.S. Geological Survey Data Series 839, accessed July 12, 2016, at http://dx.doi.org/10.3133/ds839.

Guy, K.K., and Plant, N.G., 2014, Topographic lidar survey of Dauphin Island, Alabama and Chandeleur, Stake, Grand Gosier, and Breton Islands, Louisiana, July 12-14, 2013: U.S. Geological Survey Data Series 838, accessed July 12, 2016, at http://dx.doi.org/10.3133/ds838. Joint Airborne LiDAR Bathymetry Technical Center of Expertise (JALBTCX), 2006, 2004 US Army Corps of Engineers (USACE) Topo/Bathy Lidar-Alabama, Florida, Mississippi, and 
North Carolina: Charleston, S.C., National Oceanic and Atmospheric Administration (NOAA) Ocean Service, Office for Coastal Management, metadata accessed December 15, 2015, at https://coast.noaa.gov/dataservices/Metadata/TransformMetadata? $\mathrm{u}=\mathrm{http} / / /$ coast.noaa.gov/data /Documents/Metadata/Lidar/no_harvest/usace2004_m19_metadata.xml\&f=html.

Kranenburg, C.J., Long, J.W., and Zawada, D.G., 2016a, EAARL coastal topography-Dauphin Island, post-Hurricane Katrina, 2005: U.S. Geological Survey data release, accessed July 12, 2016, at http://dx.doi.org/10.5066/F78G8HSG.

Kranenburg, C.J., Long, J.W., and Zawada, D.G., 2016b, EAARL coastal topography-Dauphin Island, 2010: U.S. Geological Survey data release, accessed July 12, 2016, at http://dx.doi.org/10.5066/F74Q7S3M.

Long, J., Morgan, K.L.M., and Doran, K., 2016a, EAARL coastal topography—Louisiana and Alabama, March 2006: U.S. Geological Survey data release, accessed July 12, 2016, at http://dx.doi.org/10.5066/F7BZ6443.

Long, J., Morgan, K.L.M., and Doran, K., 2016b, EAARL coastal topography—Louisiana, Mississippi, and Alabama, September 2006: U.S. Geological Survey data release, accessed July 12, 2016, at http://dx.doi.org/10.5066/F7765CF4.

Long, J.W., Morgan, K.L.M., and Doran, K., 2016c, EAARL coastal topography—Louisiana, Alabama, and Florida, June 2008: U.S. Geological Survey data release, accessed July 12, 2016, at http://dx.doi.org/10.5066/F7G15XZX.

National Oceanic and Atmospheric Administration (NOAA) and Joint Airborne LiDAR Bathymetry Technical Center of Expertise (JALBTCX), 2011, 2010 US Army Corps of Engineers (USACE) Joint Airborne Lidar Bathymetry Technical Center of Expertise (JALBTCX) topobathy lidar-Alabama Coast and Florida Gulf Coast: Charleston, S.C., NOAA Ocean Service, Office for Coastal Management, metadata accessed December 15, 2015 , at https://coast.noaa.gov/dataservices/Metadata/TransformMetadata? $\mathrm{u}=\mathrm{http}: / /$ coast.noaa.gov/data /Documents/Metadata/Lidar/no harvest/usace2010 al fl m1064 metadata.xml\&f=html. National Oceanic and Atmospheric Administration (NOAA) and Joint Airborne LiDAR Bathymetry Technical Center of Expertise (JALBTCX), 2013, 2011 U.S. Army Corps of Engineers (USACE) topographic lidar-Alabama, Mississippi, and Louisiana: Charleston, S.C., NOAA Ocean Service, Office for Coastal Management, metadata accessed December 15, 2015 , at https://coast.noaa.gov/dataservices/Metadata/TransformMetadata? $\mathrm{u}=\mathrm{http}: / /$ coast.noaa.gov/data /Documents/Metadata/Lidar/no_harvest/se2011_ncmp_almsla_m2610_metadata.xml\&f=html. National Oceanic and Atmospheric Administration (NOAA), U.S. Geological Survey (USGS), and National Aeronautics and Space Administration (NASA), 2000, 1998 Fall Gulf Coast NOAA/USGS/NASA airborne lidar assessment of coastal erosion (ALACE) project for the U.S. coastline: Charleston, S.C., NOAA Ocean Service, Office for Coastal Management, metadata accessed December 15, 2015, at https://coast.noaa.gov/dataservices/Metadata/TransformMetadata? $\mathrm{u}=\mathrm{https} / /$ coast.noaa.gov/ data/Documents/Metadata/Lidar/harvest/atm1998_fall_gulf_coast_m22_metadata.xml\&f= html.

Nayegandhi, A., Brock, J.C., Sallenger, A.H., Wright, C.W., Travers, L.J., and Lebonitte, J., 2008, EAARL coastal topography-Northern Gulf of Mexico: U.S. Geological Survey Data Series 384, accessed July 12, 2016, at http://pubs.usgs.gov/ds/384/. 
Nayegandhi, A., Wright, C.W., and Brock, J.C., 2009a, EAARL-An airborne LiDAR system for mapping coastal and riverine environments, chap. 1 of Bayer, J.M., and Schei, J.L., eds., Remote sensing applications for aquatic resource monitoring: Pacific Northwest Aquatic Monitoring Partnership (PNAMP) Special Publication, p. 3-5, accessed July 12, 2016, at http://www.pnamp.org/document/2546.

Nayegandhi, A., Yates, X., Brock, J.C., Sallenger, A.H., Bonisteel, J.M., Klipp, E.S., and Wright, C.W., 2009b, ATM coastal topography-Alabama 2001: U.S. Geological Survey Data Series 418, accessed July 12, 2016, at http://pubs.usgs.gov/ds/418/.

Smith, K.E., Nayegandhi, A., Wright, C.W., Bonisteel, J.M., and Brock, J.C., 2008, EAARL coastal topography, northern Gulf of Mexico, 2007-Bare Earth: U.S. Geological Survey Data Series 400, accessed July 12, 2016, at http://pubs.usgs.gov/ds/400/.

Wright, C.W., Fredericks, X., Troche, R.J., Klipp, E.S., Kranenburg, C.J., and Nagle, D.B., 2014, EAARL-B coastal topography, eastern New Jersey, Hurricane Sandy, 2012-First surface (version 1.1, August 18, 2014): U.S. Geological Survey Data Series 767, accessed July 12, 2016, at http://dx.doi.org/10.3133/ds767. 
ISSN 2331-1258 (online)

https://doi.org/10.3133/ofr20171031 